\title{
İmkan ve Sınırlar, Sorunlar ve Çözüm Önerileri Bağlamında Cami Rehberliği Hizmeti
}

\section{Mosque Guidance Practice in the Context of Possibilities and Boundaries, Problems and Solution Proposals}

\section{Mustafa Fatih Ay}

Dr. Öğr. Üyesi, Akdeniz Üniversitesi, İlahiyat Fakültesi, Din Eğitimi Bilim Dalı

Assist. Prof., Akdeniz University, Faculty of Theology, Department of Religious Education Antalya / Turkey

mustafafatihay@gmail.com | https://orcid.org/0000-0003-0433-318X

Article Type / Makale Tipi

Research Article / Araştırma Makalesi

DOI: $10.33420 /$ marife. 874871
Article Information / Makale Bilgisi

Received / Geliş Tarihi: 5.02.2021

Accepted / Kabul Tarihi: 01.05.2021

Published / Yayın Tarihi: 30.06.2021

Cite as / Atıf: Ay, Mustafa Fatih. “İmkan ve Sınırlar, Sorunlar ve Çözüm Önerileri Bağlamında Cami Rehberliği Hizmeti”. Marife 21/1 (2021), 79-103. https://doi.org/10.33420/marife.874871

Plagiarism / Intihal: This article has been reviewed by at least two referees and scanned via a plagiarism software. / Bu makale, en az iki hakem tarafindan incelendi ve intihal içermediği teyit edildi.

\section{(c) $(\rightarrow)$}

Copyright / Telif Hakkl: "This article is an open access article distributed under the terms and conditions of the Creative Commons Attribution-NonCommercial-NoDerivatives 4.0 (CC BY-NC-ND 4.0) International License." / "Bu makale Creative Commons Alıntı-GayriTicari-Türetilemez 4.0 (CC BY-NCND 4.0) Uluslar arası Lisansı altında lisanslanmıștır."

e-ISSN: $2630-5550$ 


\section{İmkan ve Sınırlar, Sorunlar ve Çözüm Önerileri Bağlamında Cami Rehberliği Hizmeti}

\section{Özet}

Cami Rehberliği ilk defa dönemin, Diyanet Isşleri Başkanlığı'ndan sorumlu Başbakan Yardımcısı Bekir Bozdağ tarafından 2012 yılında gündeme getirilmiştir. Bu hizmet alanı halen Diyanet Isşleri Başkanlığı, Din Hizmetleri Genel Müdürlüğü bünyesinde Cami Hizmetleri Daire Başkanlığı tarafindan Cami Rehberliği Hizmetleri adıyla sürdürülmektedir. Bu çalıșmada genel olarak cami rehberliği hizmeti ele alınmıștır. Bu çerçeve altında ise, cami rehberliği hizmetinin ortaya çıkıșı, amacl ve kurumsallaşma süreci, hizmeti yürüten personelin uygulamaya ilişkin değerlendirmeleri ele alınmıștır. Böylelikle de cami rehberliği hizmetinin uygulama sürecine ilișkin durum değerlendirmesi yapılması amaçlanmaktadır. Bu çerçevede cami rehberleri ile yapılan görüşmelerde, cami rehberliğine yükledikleri anlam, görevleri süresince karşılaștıkları sorunlar, kendilerini en çok sorulan sorular, desteğe ihtiyaç hissettikleri konular, cami rehberliği hizmetinin geliştirilmesi için neler yapılabileceği, kişi veya kurumlardan hangi katkıların gelebileceği konuları merkeze alınmıștır. Veri toplama sürecinde yarı yapılandırılmış görüşmeler gerçekleștirildiği için görüşmeler sırasında gerekli görülen konular da ele alınmıștır. Nitel araștırma yaklaşımlarından fenomenolojik araştırma olarak kurgulanan bu çalıșma ile cami rehberlerinin, cami rehberliği hizmetine ilişkin algı ve deneyimlerinin nasıl olduğu ilk elden ortaya konulmaya çalışılmıştır. Bu çerçevede Antalya İl Müftülüğü bünyesinde çeşitli İlçe Müftülüklerine bağlı olarak görevlendirme ile bu hizmeti yürüten 7 cami rehberi çalışma grubu olarak belirlenmiștir. Görüşmeler bizzat araştırmacı tarafından 2019 yılı Eylül ayı içerisinde, katılımcılar ile randevu alınarak yüzyüze gerçekleştirilmiştir. Görüşmeler ses kayıt cihazı ile kayıt altına alınmış ve 30-45 dakika arasında süren görüşmelerin çözümlemeleri araştırmacı tarafından yapılmıştır. Cami rehberliği uygulamasını konu edinen ilk araștırma olması nedeniyle cami rehberlerinin saha tecrübesini ortaya koymaya yarayacak sorulardan elde edilen verilerin betimsel analiz tekniği ile analizi uygun görülmüştür. Bu çerçevede çözümlenen görüşme verileri Nvivo 12 Plus programına yüklenmiştir. Bu program yardımıyla tekrar tekrar okunan görüşme verileri, cami rehberlerinin saha tecrübesini yansıtacak şekilde düzenlenmiştir. Daha sonra elde edilen kod ve temalar tekrar gözden geçirilmiş ve bazı kod-tema değişiklikleri yapılmış ve son şekli verilmiştir. Elde edilen yapılar ise gerekli görülen yerlerde katılımcı görüşlerinden ilgili yapıyı en iyi açıkladığı düşünülenlere, ifadelerindeki dil ve anlatıma müdahale edilmeden bulgular kısmında yer verilmiştir. Cami rehberlerine hangi alanlarda desteğe ihtiyaçları olduğu ve cami rehberlerinin hangi konuları bilmelerinin iyi olacağını düşündükleri sorulduğunda verdikleri cevaplar çerçevesinde öne çıkan hususların, dinler tarihi bilgisi, dil ve iletişim becerisi, rehberlik yöntemi, sanat tarihi ve mimari, yabancı dilde terminoloji bilgisi alanlarının öne çıktığı görülmüștür. Cami rehberlerinin sorun olarak gördükleri hususlar ise kadro ve istihdam sorunu, materyal sorunu ve turizm rehberleri ile yaşanan sorunlar şeklindedir. Cami rehberlerine en çok sorulan soruları, cami rehberliğine ilişkin sorular, güncel politik sorular, İslam dini ile ilgili sorular şeklinde sinıflandırmak mümkündür. Buradan anlaşıldığı üzere cami rehberliği konusunda turistlerin bilgi sahibi olmadığı görülmektedir. Bu nedenle hizmetin tanıtımı konusunda havalimanları, oteller ve turistlere yönelik hizmet alanlarında bu hizmetin tanıtımı yapılabilir. Ayrıca Kültür ve Turizm Bakanlığı tarafından hazırlanan rehber ve broşürlere cami rehberliği hizmeti de eklenebilir. İslam dini ve güncel politik sorular konusunda da bir saha çalıșması yapılarak gelen soruların toplanması ve bir çalıșma grubu tarafından değerlendirilerek, geliștirilen cevaplar konusunda cami rehberlerine bilgilendirmeler yapılabilir. Ayrıca, cami rehberliği hizmeti uluslararası alanda İslamofobi ile mücadele, İslam dini ve ülkemizin tanıtımı gibi konularda önemli bir hizmet alanıdır. Disiplinlerarası özelliği nedeniyle kurumlar arası işbirliği ile çalışmalar yapılarak hizmetin kalitesinin yükseltilmesi önemlidir. Cami rehberlerinin daha spesifik alanlarda saha tecrübelerinin detaylı bir şekilde araştırıldığı çalışmaların yanı sıra hizmet alan turistlerin de cami rehberliği hizmetine ilişkin memnuniyet ve beklentilerinin ele alındığı çalışmalar yapılabilir.

Anahtar Kelimeler: Din Eğitimi, Diyanet İșleri Bașkanlığı, Cami Rehberliği, Din Hizmetleri, Cami Hizmetleri. 


\section{Mosque Guidance Practice in the Context of Possibilities and Boundaries, Problems and Solution Proposals}

\section{Summary}

In this study, generally mosque counseling service has been discussed. It is aimed to take the mosque guidance service to the academic ground and to make a situation assessment regarding the implementation process. In this context, in the interviews with mosque guides, the meaning they attribute to mosque guidance, the problems they encountered during their duties, the questions they were asked the most, the issues they needed support, what could be done to improve the mosque guidance service, and what contributions could come from individuals or institutions were examined.Since semi-structured interviews were conducted during the data collection process, issues deemed necessary were also discussed during the interviews.

With this study, which was designed as a phenomenological research, one of the qualitative research approaches. In this context, 7 mosque guides carrying out this service were interviewed in the Antalya Provincial Mufti Office.

The questions were prepared in accordance with the semi-structured interview in order to provide flexibility during the interview. The interviews were conducted face-to-face by the researcher, by making an appointment with the participants. The interviews were recorded with a voice recorder. The interviews lasted between 30-45 minutes. The analyzes of the interviews were made by the researcher. The data obtained were analyzed with the descriptive analysis technique. Interview data analyzed within this framework were uploaded to the Nvivo 12 Plus program. With the help of this program, the interview data, which were read again and again, were organized in the form of themes and codes to reflect the field experience of mosque guides. Then, the obtained code and themes were reviewed and some code-theme changes were made and the final shape was given. The structures obtained were visualized with the help of figures and, where deemed necessary, the opinions of the participants that were thought to be explained best were included in the findings section without interfering with the language and expression in their expressions.

When asked in which areas mosque guides need support and what they think it would be good for mosque guides to know, it was seen that the prominent issues within the framework of their answers were the knowledge of the history of religions, language and communication skills, guidance method, art history and architecture, and terminology knowledge in foreign languages.

The issues that mosque guides see as a problem are the problem of staff and employment, material problems and problems with tourism guides. It is possible to categorize the most frequently asked questions to mosque guides as questions about mosque guidance, current political questions, and questions about Islam.

As a result; mosque guidance service is an important service area in matters such as the fight against Islamophobia in the international arena, the religion of Islam and the promotion of our country. Due to its interdisciplinary nature, it is important to increase the quality of the service by working with inter-institutional cooperation. In addition to the studies where the field experiences of mosque guides in more specific areas are investigated in detail, studies can also be carried out to address the satisfaction and expectations of the tourists who receive service from the mosque guidance service.

Keywords: Religious Education, the Presidency of Religious Affairs, Mosque Guidance, Religious Services, Mosque Services.

\section{Giriş}

Diyanet İşleri Başkanlığı, din hizmetleri faaliyetlerini yürütmek için anayasal bir temelde görevlendirilmiş tek kurumdur. Görev çerçevesi "İslam dininin inançları, ibadet ve ahlak esasları ile ilgili işleri yürütmek, din konusunda toplumu aydınlatmak ve ibadet yerlerini yönetmek" ${ }^{1}$ şeklinde çizilen Diyanet İşleri Başkanlığı yeni gelişen şartlar ve ihtiyaçlara göre hizmet alanlarına yeni birimler ekle-

${ }^{1}$ Diyanet İşleri Başkanlığı Kuruluş ve Görevleri Hakkında Kanun (DİBKGHK), Resmî Gazete 12038 (2 Temmuz 1965), Kanun No. 633, md. 1. 
mektedir. Bu hizmet alanlarından biri de Cami Rehberliği hizmetidir. İlk defa 2012 yılında dönemin Diyanet İşleri Başkanlığı'ndan sorumlu Başbakan Yardımcısı Bekir Bozdağ tarafından gündeme getirilen² bu hizmet alanı halen Başkanlığın Din Hizmetleri Genel Müdürlüğü bünyesinde Cami Hizmetleri Daire Başkanlığı'nın bir hizmeti olarak Cami Rehberliği Hizmetleri adıyla sürdürülmektedir. ${ }^{3}$ Ancak başkanlığın yeterliklerini belirlemiş olduğu personel grubu içerisinde cami rehberleri yer almamaktadır. ${ }^{4}$ Bu çalışmada genel olarak cami rehberliği hizmeti ele alınırken özelde ise a) cami rehberliği hizmetinin teorik çerçevesi bağlamında ortaya çıkışı, amacı ve kurumsallaşma süreci, b) cami rehberliği hizmetini yürüten görevli personelin uygulamaya ilişkin değerlendirmeleri ele alınmıştır. Böylelikle de cami rehberliği hizmetinin akademik zemine taşınarak ele alınması ve uygulama sürecine ilişkin bir durum değerlendirmesi yapılması amaçlanmaktadır.

Cami rehberliği kadrosunu ilk defa gündeme getiren Bekir Bozdağ, tarihi camilerin tanıtımının konuyu iyi bilen kişilerce yapılması için böyle bir kadronun ihdas edildiğini, farklı ülkelerde dini mekanların (kilise, sinagaog vb.) mekanları bilen ve bu alanda eğitim almış kişiler tarafından yapıldığını belirterek benzer bir uygulamanın amaçlandığını açıklamıştır. ${ }^{5}$ Diyanet İşleri Başkanlığı'nın kurumsal internet sitesinde yer alan hizmet hiyerarşisinde yer verilen Cami Rehberliği Hizmetleri başlığı altında ise bu hizmetin gerekçesine yönelik açıklamalar yer almaktadır. Bu bilgiler her ne kadar 2018 yılında eklenmiş olsa da cami rehberliğinin ne'liğine ilişkin Başkanlığın bakışını ve bu hizmetin hangi ihtiyacı karşılamak için tesis edildiğini göstermektedir. Bu açıklamaya göré, Başkanlığın 2017 yılında yaptığı araștırma sonucunda Mayıs-Ekim aylarını kapsayan 6 aylık sürede çoğunluğu İstanbul, Bursa, Konya ve Antalya illerinde olmak üzere toplam 13.177 camiyi yaklaşık 12.2 milyon yerli, 3.8 milyon yabancı turist ziyaret etmiştir. Turistlerin en çok konuştukları dillerin ise İngilizce, Arapça, Rusça ve Almanca olduğu tespit edilmiştir. Oldukça yüksek sayıda gerçekleşen bu ziyaretlerde cami rehberlerinin görevi İslam dini, tarihi, mimarisi ve sanatına dair doğru ve güvenilir bilgilendirmeler yapmak olarak ifade edilmiştir. Bu hedefler çerçevesinde ihdas edilen cami rehberinin görevleri Diyanet İşleri Başkanlığı'nın görev ve çalışma yönergesinde şu şekilde sıralanmıştır;

a) Cami ziyaretlerinin cami adabına uygun olarak yapılmasını sağlamak.

b) Ziyaretleri, ilgili caminin görevlileri ile koordineli olarak gerçekleștirmek.

c) İslam Dini ile tarihi veya özellik arz eden camiler hakkında araştırmalar yapmak.

ç) Yerli ve yabancı ziyaretçilere, ziyaret edilen cami ve İslam dini hakkında doğru ve sahih bilgiler vermek.

d) Görev yaptığı camide, inceleme, araștırma veya haber yapmak isteyen,

\footnotetext{
2 Memurlar (M), “Camileri Özel Rehber Tanıtacak, Bu Amaçla 250 Kişi Alınacak” (Erişim 19 Ocak 2020).

${ }^{3}$ Diyanet İșleri Başkanlığı (DİB), "Cami Rehberliği Hizmetleri” (Erişim 19 Ocak 2020).

${ }^{4}$ Diyanet İşleri Başkanlığı (DİB), "Diyanet İșleri Başkanlığı Personel Yeterlikleri” (Erişim 19 Ocak 2020).

${ }^{5}$ M, “Camileri Özel Rehber Tanıtacak, Bu Amaçla 250 Kişi Alınacak".

${ }^{6}$ DİB, "Cami Rehberliği Hizmetleri”.
} 
araştırmacı, televizyoncu veya sinemacılar ile film veya fotoğraf çekmek isteyen ziyaretçilerin Diyanet İşleri Başkanlığınca İdare Olunan Cami ve Mescitlerdeki Teberrükât Eşyası Hakkında Yönetmelikte belirtilen usul ve esaslar çerçevesinde hareket etmesini sağlamak.

e) Görev alanı ile ilgili konularda verilen diğer görevleri yapmak. ${ }^{7}$

Cami rehberinin görevlerine ilişkin ifadeler çerçevesinde, Diyanet İşleri Başkanlı̆̆g'nın camileri ziyaret eden kişilerin her zaman müracaat edebileceği bir görevli bulmasını hedeflediği anlaşılmaktadır. Ayrıca bu görevliden, yurtdıșından gelen ziyaretçiler ile lisan problemi yaşamadan iletişim kurabilmesi, onlara doğru bilgi aktarabilmesi ve cami içerisindeki hareketliliği koordine etmesi gibi hizmetler beklenildiği anlaşılmaktadır. Bu görevi yerine getirecek personelin alımı için Diyanet İşler Başkanlığı'nın alım ilanı ilk defa 2013 yılında gerçekleşmiştir. ${ }^{8}$

4 Haziran 2013 tarihinde yayınlanan ilanda 100 kişilik kontenjan olduğu duyurulmuştur. Bu ilanda memuriyet için gerekli teknik şartların yanı sıra halihazırda asaleten görev yapan Başkanlık personelinden en az İmam Hatip Lisesi düzeyinde dini öğrenim görmüş olanlar ile son 5 yılda KPDS/YDS veya muadili bir uluslararası bir sınavdan Almanca, Arapça, Fransızca, İngilizce ve Rusça dillerinden birisinde en az 70 veya dengi puan almış olma şartını sağlayanların başvurabileceği ve sınavın sözlü olacağı belirtilmiştir. ${ }^{9}$ Sözlü sınavın kapsamına ilişkin bir bilgiye ulaşılamamıştır. Ancak, bu sınav kapsamında cami rehberliği hizmetine ilişkin olarak camilerin tanıtılması hedefi çerçevesinde din alanının yanı sıra sanat tarihi ve rehberlik gibi alanlardan sorular sorulmasının beklendiği söylenebilir. Başkanlığın 2013 yılı faaliyet raporunda yer alan bilgiye göre sınava 23 kişi müracaat etmiş bunlardan 4'ü başarılı olmuștur. ${ }^{10}$ Personel sayılarının verildiği sayfa incelendiğinde ise cami rehberi sayısı 3 olarak belirtilmektedir. ${ }^{11}$ Buna göre sınavı kazanan 4 kişiden 3'ünün göreve başladığı tahmin edilmektedir. 2014 yılı faaliyet raporunda cami rehberi sayısına ilişkin bir bilgi bulunmazken ${ }^{12}$, 2015, 2016, 2017, 2018 ve 2019 yıllarına ait faaliyet raporlarında ise 1 cami rehberi olduğu görülmektedir. ${ }^{13}$ Kadrolu olarak görevine devam eden bir cami rehberinin de İstanbul Müftülüğü bünyesinde Sultanahmet Cami'sinde olduğu anlaşılmaktadır. Kadrolu olarak istih-

${ }^{7}$ Diyanet İşleri Başkanlığı (DİB), “Diyanet İşleri Başkanlığı, Diyanet İşleri Başkanlığı Görev ve Çalışma Yönergesi” (Erișim 19 Ocak 2020).

${ }^{8}$ Memurlar (M), “Diyanet İşleri Başkanlığı Cami Rehberi Alım İlanı” (Erişim 19 Ocak 2020).

${ }^{9} \mathrm{M}$, “Diyanet İşleri Başkanlığı Cami Rehberi Alım İlanı".

${ }_{10}$ Diyanet İşleri Başkanlığı Strateji Geliștirme Başkanlığı (DİBSGB), 2013 Yılı Faaliyet Raporu (Ankara: Diyanet İşleri Yayınları, 2014), 66.

11 DiBSGB, 2013 Yll Faaliyet Raporu, 15.

12 Diyanet İșleri Başkanlığı Strateji Geliștirme Başkanlığı (DİBSGB), 2014 Yılı Faaliyet Raporu (Ankara: Diyanet İşleri Yayınları, 2015), 1-111.

${ }^{13}$ Diyanet İşleri Başkanlığı Strateji Geliştirme Başkanlığı (DİBSGB), 2015 Yılı Faaliyet Raporu (Ankara: Diyanet İşleri Yayınları, 2016), 14; Diyanet İşleri Başkanlığı Strateji Geliştirme Başkanlığı (DİBSGB), 2016 Yılı Faaliyet Raporu (Ankara: Diyanet İşleri Yayınları, 2017), 13; Diyanet İşleri Başkanlığı Strateji Geliștirme Başkanlığı (DİBSGB), 2017 Yılı Faaliyet Raporu (Ankara: Diyanet İşleri Yayınları, Tarihsiz), 16; Diyanet İşleri Başkanlığı Strateji Geliștirme Başkanlığı (DİBSGB), 2018 Yılı Faaliyet Raporu (Ankara: Diyanet İşleri Yayınları, Tarihsiz), 14; Diyanet İşleri Başkanlığı Strateji Geliștirme Başkanlığı (DİBSGB), 2019 Yılı Faaliyet Raporu (Ankara: Diyanet İşleri Yayınları, Tarihsiz), 20. 
dam edilen cami rehberi sayısı 1 kişi olsa da Antalya Müftülüğü bünyesinde halen görevlendirme ile çalışan 7 cami rehberi bulunmaktadır. ${ }^{14}$ Bu durum, cami rehberliği hizmetinin önemli bir faaliyet alanı olarak görüldüğü, bu nedenle de istenilen yeterlikte personel istihdamı yaplamamış olsa da mümkün olan çerçevede sürdürülmesi arzusunun göstergesi olarak yorumlanabilir.

Cami rehberliğine ilişkin olarak Başkanlığın 2016 yılı faaliyet raporu ve Din Hizmetleri Genel Müdürlüğü'nün 2016 yılı faaliyet raporundan 08-09 Mart 2016 tarihinde Ankara'da "Cami Rehberliği Çalıștayı" yapıldığı anlaşılmaktadır. Çalıştayın gerekçesi ise "yerli ve yabancı turistlerce gerçekleştirilen cami ziyaretlerinde ve ziyaretçilere sunulan rehberlik hizmetlerinde karşlaş̧lan sorunları ve çözüm yollarını tespit etmek, rehberlik hizmetlerinin verimliliğini artırmak ve alanda ihtiyaç duyulan düzenlemeleri görüşmek olarak ifade edilmiştir. ${ }^{15}$ Çalıştaya bazı ilçe müftüleri, vaizler, tarihi ve turistik nitelikteki camilerin din görevlileri ve cami rehberlerinin katıldığı belirtilmektedir. ${ }^{16} 2016$ yılında kadrolu olarak bir adet cami rehberi çalıştığı düşünüldüğünde buradan görevlendirme ile çalışan cami rehberlerinin olduğu anlaşılmaktadır. Çalıştay sonuç raporunun ise ilgili birimlere gönderildiği belirtilmektedir. Yayınlanmıș bir sonuç raporu bulunmadığı da düşünüldüğünde, çalıştay raporunun kurum içerisinde değerlendirildiği anlaşılmaktadır. Bununla birlikte sözkonusu çalıştaya ilişkin Din Hizmetleri Genel Müdürlüğünün faaliyet raporunda, çalıștayda ele alınan konu başlıklarının Bir Din Hizmeti Olarak Cami Rehberliğinin Önemi ve Yöntemi, Cami Ziyaretlerinde Karşılaşılan Sorunlar ve Çözüm Önerileri, Cami Rehberliğinde Paydaș Kurum/Kurulușlar ve İşbirliği İmkânları, Cami Rehberliğinde Yayın ve Materyal İhtiyacı, Cami Rehberlerinin İstihdamı ve Özlük Hakları, Cami Rehberlerinin Eğitimi şeklinde olduğu belirtilmiştir. ${ }^{17}$ Bu bilgiler ışığında Diyanet İşleri Başkanlığı'nın cami rehberliği hizmetini çok yönlü olarak ele aldığı anlaşılmaktadır. Ancak 2016 yılından sonra başkanlığın cami rehberliği konusunda bir faaliyetine rastlanmamıştır. Benzer şekilde akademik literatürde cami rehberliği hizmetini ele alan bir çalışmaya da rastlanmamıştır. Bu çalışma ile cami rehberlerinin saha tecrübesinin derlenmesi ve uygulamaya ilişkin değerlendirmelerinin alınması cami rehberliği hizmetinin geliştirilmesi için önemli katkılar sunması beklenmektedir.

Bu çerçevede çalışmanın amacı cami rehberlerinin, cami rehberliğine yükledikleri anlam, görevleri süresince karşılaştıkları sorunlar, kendilerini en çok sorulan sorular, desteğe ihtiyaç hissettikleri konular, cami rehberliği hizmetinin geliştirilmesi için neler yapılabileceği, kişi veya kurumlardan hangi katkıların gelebileceği hususlarını ortaya koymak olarak belirlenmiştir. Problem cümlesi ise cami rehberlerinin, cemi rehberliği hizmeti deneyimleri nasıldır? şeklinde belirlenmiştir.

\footnotetext{
14 İstanbul Müftülügü (İM), "Personelimiz” (Erişim 19 Ocak 2020).

15 DİBSGB, 2016 Yllı Faaliyet Raporu, 37; Diyanet İşler Başkanlığı Din Hizmetleri Genel Müdürlüğü (DİBHGM), Faaliyet Raporu 2016 (Ankara: Diyanet İşleri Yayınları, 2017), 107.

16 DIBHGM, Faaliyet Raporu 2016, 107-108.

17 DİBHGM, Faaliyet Raporu 2016, 108.
} 


\section{Yöntem}

\subsection{Araştırma Deseni}

Nitel araştırma yaklaşımlarından fenomenolojik araştırma olarak kurgulanan bu çalışma ile cami rehberlerinin, cami rehberliği hizmetine ilişkin algı ve deneyimlerinin nasıl olduğu ilk elden ortaya konulmaya çalışılmıştır. Fenomenolojik araştırma; birkaç kişinin bir fenomen veya kavramla ilgili yaşanmış deneyimlerinin ortak anlamını ifade etmektedir. ${ }^{18}$ Böylelikle cami rehberlerinin, cami rehberliğine iliş̧kin yaşadıkları deneyimlerin anlaşılması hedeflenmiștir.

\section{2. Çalışma Grubu}

Fenomeni deneyimleyen kişiler olarak cami rehberleri hedef kişiler olarak belirlenmiștir. Bu çerçevede Antalya İl Müftülüğü bünyesinde çeşitli İlçe Müftülüklerine bağlı olarak görevlendirme ile bu hizmeti yürüten 7 cami rehberi çalışma grubu olarak belirlenmiștir. Araştırmanın saha araştırması yapıldığı sırada (Eylül 2019) Türkiye genelinde kadrolu olarak 1 cami rehberi İstanbul'da görev yapmakta olup Antalya'da ise görevlendirme ile 7 cami rehberi görev yapmaktadır. ${ }^{19}$ Katılımcılara ilişkin görev yeri, öğrenim durumu ve hizmet verdiği yabancı dil bilgileri aşağıda tablo da verilmiştir. Katılımcıların isimlerinin gizli kalması amacıyla verilen kod isimler ile katılımcı bilgileri tabloda eşleştirilmemiştir. Kod isimlerin verilmesinde ise katılımcının kısaltması olarak kullanılan " $\mathrm{K}$ " yerine cami rehberini ifade etmesi için rehberin ilk harfi olan "R" kullanılmıștır.

Tablo 1. Katılımcılara İlişkin Bilgiler

\begin{tabular}{cccc}
\hline Görev Yaptığı Cami & Görev Yaptığı İlçe & Eğitim Durumu & Yabancı Dili \\
\hline $\begin{array}{c}\text { Develili İbrahim } \\
\text { Buğday Cami }\end{array}$ & Aksu & $\begin{array}{c}\text { İlam Hukuku ve Medeni- } \\
\text { yeti (Yurt Dışı) }\end{array}$ & İngilizce \\
\hline Huzur Cami & Kemer & İlahiyat Fakültesi & Rusça \\
\hline Yivli Minare Cami & Muratpaşa & $\begin{array}{c}\text { İlahiyat Meslek Yüksek } \\
\text { Okulu - İşletme Lisans }\end{array}$ & Almanca \\
\hline Alanya Kale Cami & Alanya & $\begin{array}{c}\text { Turizm ve Otel İşletmeci- } \\
\text { liği - İşletme Lisans }\end{array}$ & İngilizce \\
\hline Külliye Cami & Manavgat & İlahiyat Ön Lisans & Almanca \\
\hline Kadriye Mahallesi & Serik & $\begin{array}{c}\text { Turizm Rehberliği - İlahi- } \\
\text { yat Fakültesi }\end{array}$ & İngilizce \\
\hline Dinler Bahçesi Cami & Serik & Kazak Dili (Yurt Dişı) - & Rusça - Kazakça \\
\hline $\begin{array}{c}\text { Belek Mahallesi } \\
\text { Cami }\end{array}$ & & İlahiyat Ön Lisans & \\
\hline
\end{tabular}

\footnotetext{
${ }^{18}$ John. W. Creswell, Nitel Araştırma Yöntemleri: Beş Yaklaşıma Göre Nitel Araştırma ve Araştırma Deseni, ed. Mesut Bütün - Selçuk Beşir Demir (Ankara: Siyasal Kitabevi, 2015), 77.

19 İ̈, "Personelimiz"; DİBSGB, 2019 Yllı Faaliyet Raporu, 20.
} 


\subsection{Verilerin Toplanması}

Cami rehberliği hizmetine ilişkin literatür taraması yapılmış özellikle basında yer alan tartışmalar ve resmi makamlar tarafından yapılan açılklamalar incelenerek katılımcılar ile yapılacak görüşmeler için sorular hazırlanmıştır. Bu sorular ilk olarak katılımcılardan biri ile yapılan pilot görüşmede sorulmuş ve son düzenlemeleri yapılmıştır. Sorular, görüşme sırasında esneklik sağlaması açısından yarı yapılandırılmış görüşmeye uygun şekilde hazırlanmıștır. Görüşmeler bizzat araştırmacı tarafından 2019 yılı Eylül Ayı içerisinde, katılımcılardan randevu alınarak yüzyüze gerçekleştirilmiştir. Görüşmeler ses kayıt cihazı ile kayıt altına alınmış ve 30-45 dakika arasında süren görüşmelerin çözümlemeleri araştırmacı tarafından yapılmıştır.

\subsection{Verilerin Analizi}

Cami rehberliği hizmetini konu edinen ilk araștırma olması nedeniyle cami rehberlerinin saha tecrübesini ortaya koymaya yarayacak sorulardan elde edilen verilerin betimsel analiz tekniği ile analizi uygun görülmüştür. ${ }^{20}$ Bu çerçevede çözümlenen görüşme verileri Nvivo 12 Plus programına yüklenmiştir. Bu program yardımıyla tekrar tekrar okunan görüşme veriler, cami rehberlerinin saha tecrübesini yansıtacak şekilde tema ve kodlar şeklinde düzenlenmiştir. Daha sonra elde edilen kod ve temalar tekrar gözden geçirilmiş ve bazı kod-tema değişiklikleri yapılmış ve son şekli verilmiştir. Elde edilen yapıları, gerekli görülen yerlerde katılımcı görüşlerinden en iyi açıkladığı düşünülenlere, ifadelerindeki dil ve anlatıma müdahale edilmeden bulgular kısmında yer verilmiștir.

\section{Bulgular}

\subsection{Cami Rehberliğine Yüklenen Anlam}

Katılımcılara cami rehberliğini nasıl anlamlandırdıkları konusundaki görüşlerinin sorulduğu soruya bazı katılımcılar "Cami hakkında İslam hakkında tanıtım ve bilgilendirme yapmaktır."21 R6 ise "Cami kültürünü, İslam kültür ve medeniyetini merak ettiklerini anlatıyoruz." 22 şeklinde kısa ifadeler ile cevap verirken bazı cami rehberleri ise benzetmeler ve yeni kavramsallaştırmalar yaparak geniş bir çerçevede açılamıştır. Örneğin R3 cami rehberliğinin, caminin tanıtımı ve İslam dininin anlatımından daha geniş bir çerçevede olduğunu, Türk toplumunun tanıtılmasının da bu hizmet içerisinde değerlendirilmesi gerektiğini şu sözlerle anlatmaktadır: "Gelen yabancılara sıcak bir lisan, bir adım lazım. Bizi kendi ülkelerinden, dışarıdan yanlış görüyorlar, yanlış tanıyorlar. Sadece İslam anlatmıyoruz. Ge-

\footnotetext{
${ }^{20}$ Ali Yıldırım - Hasan Şimșek, Sosyal Bilimlerde Nitel Araştırma Yöntemleri (Ankara: Seçkin Yayıncılık, 2006), 224.

${ }^{21}$ R7, Kișisel Görüșme, 18 Eylül 2019.

${ }^{22}$ R6, Kişisel Görüşme, 10 Eylül 2019.
} 
leneklerimizi, göreneklerimizi, alışkanlıklarımızdan toplumuzdan anlatıyoruz. Toplumuzun aynasıyız. Çok farklı milletlerden gelenler var. Onların adres gördügü kişi olarak, görüyor. Şehirle ilgili başka şeylerde soruyorlar, ilgilerini çeken şeyleri de soruyorlar. Toplumdaki birisinin bir davranışının nedenini de bize soruyorlar."23

Cami rehberliği hizmetini İslamofobi sorununa karşı bir imaj faaliyeti olarak nitelendiren R2 ise bu konuda şunları söylemektedir: "Bir tavır bu imaj make up diye bir şey bu. Biliyorsunuz İslamofobi mi dersiniz korku mu dersiniz tehlike olarak adlandırılan bu kötü propaganda neticesinde İslam'ın ve Türk milletinin imajı ciddi manada oynanıyor yani bir yerlerde bir laboratuarlarda gün be gün bu konularda kötü propaganda yapilıyor ve buraya gelenlerden de biz bunu hissediyoruz. Sordukları soru, merak ettikleri şeyler, bir şekilde biz image makerlık yapıyoruz. Yani Türkiye'nin ve İslam'ın bozulan imajıyla ilgili düzeltmelerin peşindeyiz. Yani mimariden de anlatıyoruz ama bizim önceliğimiz mimari değil mimarinin iç dünyası, maneviyatı burada yapılan faaliyetler bizi ilgilendiren esas $0 .{ }^{\prime 24} \mathrm{R} 2$ 'nin imaj düzeltme olarak nitelediği durumu, R3 şu örnek ile desteklemektedir: "İnsanların bizim dinimizi ahlaki şeylerimizi öğrenmeleri gerekir. Dışarıdan bizi kötü görüyorlar. Norveçli bir aile biz sizi böyle tanımıyorduk, basında, televizyonda sizi böyle tanıtmıyorlar, burada sizleri görünce anladık bunu diyorlar."25

Bu çerçevede cami rehberliği hizmeti cami rehberleri tarafından cami ve İslam dininin tanıtımının yanı sıra Türk ve Müslüman imajının düzeltilmesi ve İslamofobi ile mücadele etme hizmeti şeklinde anlamlandırıldığı söylenebilir. Ek olarak R2'nin şu sözleri: “Diyanet dışındaki bir kişinin buraya alınması söz konusu değil. Alınmamalı da çünkü bu kurumun ve dini hassasiyetlerin farkında olamazlar diğerleri."”26 Cami rehberliğinin Diyanet İșleri Başkanlığı personeli tarafından alanında uzman kişiler tarafından verilmesi gereken bir hizmet olarak görüldüğünü göstermektedir.

\subsection{Cami Rehberlerinin Desteğe İhtiyaç Duyduğu Konular}

Cami rehberlerine hangi alanlarda desteğe ihtiyaçları olduğu ve cami rehberlerinin hangi konuları bilmelerinin iyi olacağını düşündükleri sorulduğunda verdikleri cevaplar çerçevesinde öne çıkan hususların; dinler tarihi bilgisi, dil ve iletişim becerisi, rehberlik yöntemi, sanat tarihi ve mimari, yabancı dilde terminoloji bilgisi olduğu görülmüştür.

\subsubsection{Dinler Tarihi Bilgisi}

Dinler tarihi konusunda daha fazla bilgiye ihtiyacı olduğunu belirten R6 bu durumu şu sözleri ile açıklamaktadır: "Dinler tarihi konusunda eksikliklerimiz var. İlahiyatta her ne kadar dersi alsak da eksiklerimiz var. Muhatap olduğumuz kişile-

\footnotetext{
${ }^{23}$ R3, Kișisel Görüşme, 5 Eylül 2019.

${ }^{24}$ R2, Kişisel Görüşme, 17 Eylül 2019

${ }^{25}$ R3, Kişisel Görüşme, 5 Eylül 2019.

${ }^{26}$ R2, Kişisel Görüşme, 17 Eylül 2019.
} 
rin dinlerini bilmemiz gerekiyor. 0 konuda eksiklerim var. Eğitim alsak güzel olur yani." ${ }^{27}$ Katılımcının ifadesinden anlaşıldığı üzere, farklı dinlere mensup kișiler ile muhatap olan cami rehberi, muhatap olduğu kişilerin dinleri hakkında bilgi sahibi olmanın kendisine faydalı olacağını düşünmektedir. Farklı dinlere ait kavramları biliyor olmaları cami rehberlerinin, muhatapları ile daha başarılı iletişim kurmalarına imkân tanıyacağı düşünülmektedir.

Bir diğer katılımcı ise cami rehberlerinde bulunması gereken özellikler üzerinden, bir mesleki eğitim düzenlenmesi durumunda gereken içeriği sıralarken, mukayeseli bir şekilde dinler tarihini ve farklı dinlerin mezheplerinin öğretilmesi gerektiğini vurgulamaktadır. "Okumaya meraklı bir insan olacak, mukayeseli okumalar yapacak İslam buna ne dedi “Kur’an buna ne dedi İncil de ne var Tevrat’ta ne var gibi onların argümanlarını onarın mahallelerini onların duygularını onların davranışlarını Hıristiyanların ibadetlerini bunları şunları bilecek yani. Dinler tarihini bilecek. Dinler tarihini mezhepler tarihini de bilecek. Yani Katolikliği, Ortodoksluğu, Yahovayı, Protestanlı̆̆ı bunları bilecek yani. Süryaniliği ya da Yezidiliği bunları karşılığı ne bunları bilmek zorunda. Kendi İslam mezhepler tarihini de bilecek yani teoloji ve mezhepler tarihi ile ilgili okumalar yapacak. Eğer bir meslek eğitimi verilecekse onun içinde bunlar da olmalı, niye bu bizim burada iki dakikalık konuşmamıza içinde iki tane cümle sığdırabiliriz ki o iki cümlenin arka planı belki iki bin sayfadır. Ama tam legonun uygun parçası gibi oraya luk oturur. Sonrasını konuşmanıza gerek yok. Yani batılılar bu konu da çoğunluğu bu muhabbeti yapıyorsa anlayış düzeyi yüksektir."28

\subsubsection{Dil ve İletișim Becerisi}

Dil ve iletişim konusu da katılımcıların görevlerini yaptıkları süreçte önemli olduğunu vurguladıkları hususlar arasındadır. Bu alanda katılımcıların görüşlerini iki boyuta ayırmak mümkündür bunlardan birincisi beden dili, jest ve mimik kullanımı iken, diğeri ise iletişimde kültürel kodların farkına varmadır. Beden dili kullanımının önemine ilişkin katılımcı görüşleri şu şekildedir: "Beden dili etkileşimi çok önemli; yüzünüzdeki halleri, mimikleri çok iyi inceledikleri için inandırıcılık ve doğru söyleyip söylemediğinizi kendilerince çıkarımda bulunuyorlar. Bu da inandırıcılığı etkiliyor. Muhatabınızla aranızdaki sohbetin yönüne şekil veriyor bu yönden bu özellikler önemlidir." 29

"Görgü eğitiminin olmasını isterim. Kesinlikle el kol hareketleri, şan bunların olmazsa olmazı var. Ses, sesi kontrol etme yani vücut dilini kullanma, yurt dışı olmazsa olmaz. Her sene bir veya iki ay bizim teşkilatlarımız var dünyada. Dünya da her sene değișik ülkelere bu arkadașların minimum bir ay, iki ay gönderilerek orada yoğun gözlem ve konuşma, muhabbet olayı yerinde görme onların yaşantılarını, bakkalda pazarda nasıl yaşadıklarını görmek zorundalar ki burada o kısacık dakikalara en değerli sunumları sığdırabilsinler. Böyle televizyondan seyretmekle

\footnotetext{
${ }^{27}$ R6, Kișisel Görüşme, 10 Eylül 2019.

${ }^{28}$ R2, Kișisel Görüșme, 17 Eylül 2019.

${ }^{29}$ R4, Kişisel Görüşme, 26 Eylül 2019.
} 
olacak bir şey değil. Yani dil puanından 100 alan bir adam burada süper rehberlik yapamaz yani usul bilmiyorsa, erkân bilmiyorsa. Her yerde öyledir usulsüz vusul olmaz der atalar. Bu adamların dünyasını bilmiyorsa ki önerimiz oydu rehberin yılın en az bir buçuk iki ayında kış döneminde yurt dışındaki diyanetin merkezlerinde tecrübe eğitimine dil eğitimine gönderilmesiydi. Bizim projelerimizden birisi onların her sene geri geldiğinde daha zinde daha yenilenmiş olarak turizm sezonuna girmesini sağlayıcı bir teklifti." 30

R2'nin vurguladığı ikinci husus ise iletişimde kültürel kodların önemidir. $\mathrm{Bu}$ kodların rehberler tarafından öğrenilebilmesi için R2 kendi yurtdışı tecrübesinin önemini vurgulamakta ve bu tecrübenin geliştirilebilmesi için Diyanet İşleri Başkanlığı'nın imkanlar sunmasının faydalı olacağını belirtmektedir. Kültürel kodların iletişimdeki rolünü vurgulayan bir diğer katılımcı ise R6'dır. 0 da muhatabın talepte bulunmaması halinde ısrarcı olunmaması konusuna şu ifadeler ile dikkat çekmektedir: "Talep etmiyorsa veya detay istemiyorsa onlar için iletişim konusunda aşmaya gerek yok." ${ }^{31} \mathrm{Bu}$ ifadelerden de anlaşılacağı üzere muhatabın beden dilinden anlamak önemlidir. Bilgi talep edenin fark edilmesi kadar, talepte bulunmayanın da rahatsız edilmemesi için bu konu önemlidir.

\subsubsection{Rehberlik Yöntemi}

Cami rehberlerinin vurguladığı bir diğer husus ise doğrudan bir hizmet faaliyeti olarak bu işin bir yöntemi olması gerektiği ve bu yöntem konusunda destek almalarının faydalı olacağıdır. Bu konuda rehberler tarafından ilk etapta farklı bir dinden olan muhataba İslam dini hakkında hangi bilgilerin verilmesi gerektiği konusudur. Örneğin R6 "Bir Hristiyana en başta İslam adına verilmesi gereken bilgi nedir bunu düşünmemiz lazım. Savaşlardan önce peygamber efendimizin güzel huylarını, tüm huyları güzel de barıștan yana olduğu tarafları vermemiz lazım"32 şeklinde hem sorunu hem de kendi bulduğu çözümü aktarmaktadır.

Bir diğer rehber ise bu konuda yöntem eksikliğinden ve arayışlarının sonuçsuz kaldığından bahsetmektedir: "Rehber arkadaşlarla yabancı dilde diğer dinleri de kapsayıcı insan psikolojisiyle ilgili hizmet içi eğitimlere tabi tutulsak yararlı olurdu. Ama böyle bir metodoloji yok. Bence olması gerekir. Biz Müslümanlar, özellikle de cami rehberleri, yabancı biriyle ilk önce ne gibi konulardan başlanması gerektiğinin bir eğitiminin verilmesi gerekir. İslam’ın birçok mesajı var. Mesela, biz konuşurken ilk başta namazdan giriyoruz. İlk önce namazdan mı başlamak lazım? Yoksa kelime-i şehadetten mi başlamak lazım? İmanın şartlarından mı başlamak lazım? Bununla ilgili bir metot yok. Bugün en basit bir din eğitiminde bile bir metodoloji var. Ama din gibi insanlık tarihiyle var olan bir olgunun insanlara nasıl anlatılması gerektiğinin bir metodolojisi yok. Bakıyoruz kitaplara, Hz. Peygamber'e Hira Mağarası'nda vahiy geldi. 622'de böyle oldu. 610'da şu oldu. Bunlar zaten o dönemin tarihselliği. Ama Hz. Peygamber'in ilk neyi öğretmeye başladığıyla ilgili

\footnotetext{
${ }^{30}$ R2, Kișisel Görüşme, 17 Eylül 2019.

${ }^{31}$ R6, Kişisel Görüşme, 10 Eylül 2019.

${ }^{32}$ R6, Kişisel Görüşme, 10 Eylül 2019.
} 
çok fazla bir bilgi yok. Mesela, buraya bir İslam tarihi hocası geldi. "Biz yabancllarla muhatabız. İslam'ın ana mesajını ileten bir kitap var mı?" diye sordum. Bana bir kitap göndermiş. Aynı siyer ve İslam tarihi gibi bir kitap." 33

Yine R5'in dikkat çektiği bir diğer husus da yöntem eksikliğinin bir konuşma gündemi olușturmaya engel olduğunu, suni gündemlere göre hareket ettiklerinden yakınmaktadır: "Biz suni gündemlerle insanlara bilgi paylaşıyoruz. Bu da insanlarda kalıcı olmuyor. Çünkü karşımızdaki insanın psikolojisini, bilgiyi nasıl vermemiz gerektiğini, hangi bilgiden başlamamız gerektiğini bilmiyoruz. Bununla ilgili çalışma yapılması lazım." ${ }^{34}$

Rehberlik yöntemi konusunda rehberlerin dikkat çektiği bir diğer husus da muhatabın seviyesine ve tercihine uygun bir yöntem kullanılmasıdır. R2 bu konuda muhatap ile zamanın sınırlı olduğunu ve muhatabının İslam dini konusunda bilgi sahibi olmadığından hareketle ne söylemesi gerektiği konusunda zorlandığını anlatmaktadır: "Gelen insanın hiçbir şey bilmediğini birçok şeyi yanlış bildiğini bilerek ona bir ilkokul çağı çocuğu seviyesinde yaklaşmak durumundayız. Yani rahat bir kafayla işe başlamak zorunda buradaki kişi yani sinirli stres buna benzer gerginlik... Bu iş tamamen psikolojiyle yapılan bir iş bunu biliyorum. Bir adam şöyle düşünür dışarıdan birisi geldi size bir dakikasını ayırdı sadece bir dakika size üç dakikasını ya da beş dakikasını ayırdı ortalama budur. Siz bir üç beş dakikaya öyle şeyler sığdırmalısınız ki tam nokta atışı olmalı ve geri çekilmelisiniz. Beyin öyle bir çalışma yapıyor o süreçle ilgili o bir dakika benim normal hayattaki yaklaşılk iki saatime bedel. 0 kadar yoruluyor beyin ben acaba neyi söylememeliyim kesinlikle acaba neyi söylemeliyim kesinlikle." 35

R5 ise bu konuda şunları söylemektedir: "Buraya öyle gruplar geliyor ki, ilkokul seviyesinden profesör düzeyine dek. Kişinin profilini iyi bir şekilde anlayıp ona göre bilginizi paylaşmanız lazım. Yoksa çok sağlıklı bir bilgi veremezsiniz." 36 Terminolojiyi doğru kullanmanın nitelikli bir iletişimi sağlamaya yeterli olmadığı$\mathrm{nl}$, bazen muhatabın anlayacağı şekilde konuyu açmak gerektiği konusuna dikkat çeken R5 yaşadığı örneği şu sözlerle anlatmaktadır: "Örneğin; içlerinde bir İngiliz profesörün olduğu bir grup camiye gelmişti. Ben "Bismillahirrahmanirrahim"in anlamını verdiğimde boş boş bakıyorlardı. Acaba kelimeyi yanlış mı telaffuz ediyorum diye düşündüm. Her yerden kontrol ediyorum ama doğru söylüyorum. Sonradan bir yabancı dil uzmanına sorduğumda "Bu kelime evet senin çevirdiğin gibi geçiyor. Ama senin bunu açarak anlatman lazım. Yoksa karşındaki kişi bunu anlamaz." dedi." ${ }^{37} \mathrm{Bu}$ örnekten anlaşılacağı üzere doğru bir şekilde ifade edilmesi için gayret edildiğinde gündelik dil kullanan ve alanda uzman olmayan kişilerin anlayacağı dilden uzaklaşılmaktadır. Bu noktada hem terminolojiyi doğru kullanmak hem de basit bir dille anlatımın anlaşılırlığını sağlayacak yöntemler geliştirmek

\footnotetext{
${ }^{33}$ R5, Kişisel Görüşme, 3 Eylül 2019.

${ }^{34}$ R5, Kișisel Görüşme, 3 Eylül 2019.

${ }^{35}$ R2, Kişisel Görüşme, 17 Eylül 2019.

${ }^{36}$ R5, Kişisel Görüşme, 3 Eylül 2019.

${ }^{37}$ R5, Kişisel Görüşme, 3 Eylül 2019.
} 
önemli görünmektedir.

\subsubsection{Sanat Tarihi ve Mimari}

Rehberlerin muhatapları ile iletişiminde destek ihtiyacı hissettiklerini belirttiği diğer bir konuda sanat tarihi ve mimari konusudur. Bu konuda muhataplarının cami ile genelde karşılaştırma yapmalarından dolayı, kilise mimarisi ve iç düzeni hakkında bilgi sahibi olmanın gerekli olduğunu düşünen R6 bu konuda şunları söylemektedir: "Kilise ile camiyi karşılaştırıyorlar, namaz kılınan yerin özelliklerini soruyorlar. Onlarda ibadet resimlerin ne derler ikonaların önünde oluyor, ibadet yapılıyor. 0 yüzden ikonaları tanımamız gerekiyor. Kilise kültüründe ikonalar neden önemli bilmemiz gerekiyor. Önemli şahsiyetlerin resimleri vs. bu konuda bilgi sahibi olmalıyı." 38

Bir diğer rehber ise cami konusunda anlatım yaparken görev yaptığı caminin mimarisi hakkında detaylı bilgi sahibi olma ihtiyacından bahsetmektedir. "Cami dizayn ve dekorasyonu ile ilgili. Benim camimde dizayn dekorasyon başka camideki ile ilgili aynı değil. Benim camimde Selçuklu, Osmanlı ve yeni Türk modern stil var bu konuda eğitim almamız gerekiyor. Adı çeşitli olabilir ama eğitim almamiz gerekiyor". 39

\subsubsection{Yabanci Dilde Terminoloji Bilgisi}

Cami rehberliği hizmetinin, İslam dininin farklı dil ve dinlerde muhataplara anlatılmasını içerdiği düşünüldüğünde, öne çıkması kaçınılmaz olan bir konu da yabancı dilde dini terminoloji sorunu olduğu görülmektedir. Bu konuda teoloji ve dinsel terminolojinin dil bilmekten öte bir şey olduğunu vurgulayan R2 şunları söylemektedir: "Şimdi siz bir dinden bahsederken o dinin terminolojisinin yabancı dildeki uygun olan karşılığını bulacaksınız. Bu çok kolay bir şey değil. Birisinin de öğretmenlik yapmasını istiyorum. Aradığım günler oluyor. Yani keşke birisine danışabilsem, birisiyle bu konuyu görüşebilsem, birisinden akıl alabilsem diye birçok defa aradığım oldu. Çünkü birçok defa çetin kelami tartışmalar yapıyoruz buraya papaz da geliyor her şey geliyor bilmiyorsun kim olduğunu. Teoloji profesörü geliyor, Berlin bu konuda iyidir yani. Almanya teoloji şarkiyat enstitüleri, Türkoloji enstitüleri, teoloji enstitüleri Almanya'nın hatrı sayılırdır. Öyle uyduruktan teyyare değil. O zaman diyorum ki şu kelimelerimin yetmediğini hissediyorum açık söyleyeyim. Bu gocunacak bir taraf yok bunun eğitimini almadık biz. Kelimeler yetmiyor. Türkçe anlatsam problem yok ama rastgele bir kelimede anlatamazsınız ki çünkü İslam terminolojisindeki bir kelimenin aynı içsel manası duygusuyla birlikte Almancada yok. Siz birkaç kelimeyle onu anlatmak durumundasınız. Hep bu örneği veriyorum secde meselesini anlatırken karşılığı sihboygendir (Sich beugen) şuursuzca kendini yere atmak diye geçer sözlükte. Siz secdeyi sihboygen (Sich beugen) deyin gülüyorlar. Yani kendini şuursuzca kendini yere atınca ne yapmış oluyorsun

\footnotetext{
${ }^{38}$ R6, Kișisel Görüșme, 10 Eylül 2019.

${ }^{39}$ R7, Kişisel Görüşme, 18 Eylül 2019.
} 
ki diyor doğal olarak. Ama o secdeyi Allah ile en yoğun muhabbetin olduğu mekân demek için kullandığınız kelimelere bir bakın ve onu hissettirmeniz lazım. 0 zaman ihtiyaç hissediyorum. Keşke bir atölyemiz olsa bu atölye de daha iyi bilenlerle saha tecrübeleri olanlar bu konu da hem usul hem içerik hem sunum üzerine böyle thinktank diyorlar ya fikir alışverişleriyle birlikte biz zihnimizi ve günümüzü ve güncelimizi sürekli aktüel hale getirebilsek. ${ }^{40}$

R2 geniş bir şekilde açıkladığı terminoloji problemi, oldukça önemlidir. Zira tarih boyunca dil, kültür ve dinin karşılıklı etkileşimi sonucunda ortaya çıkan kavramlar ve ifadelerin farklı bir din, kültür ve din kapsamında ifade edilmesi oldukça güçtür. Bu noktada R2'nin de vurguladığı gibi ciddi çalışmalar yapılması ve uygun ifade etme konusunda İlahiyat fakülteleri ilgili yabancı dil bölümleri veya uzmanlarının işbirliği yapması elzemdir.

\subsection{Cami Rehberlerinin Sorun Olarak Gördükleri Hususlar}

Cami rehberlerinin sorun olarak gördükleri hususlar ise kadro ve istihdam sorunu, materyal sorunu ve turizm rehberleri ile yaşanan sorunlar şeklindedir.

\subsubsection{Kadro ve İstihdam Sorunu}

Rehberlerin sorun olarak gördükleri konular sorulduğunda öne çıkardıkları hususlardan biri cami rehberi kadrosunda değil de görevlendirme usülü ile çalışmaları olmuştur. Kadro sıkıntısı konusunda önemli bir engel olarak görülen hususun, şartlar arasında yer alan 70 yabancı dil puanı olduğu söylenebilir. Bu konuda R3 şunları söylemektedir: "Görevlendirme olarak çalışıyoruz. 70 puan şartı var. Yds 40-45, günlük yaşamda sorunum yok herşeyi anlatırım, ama toprak, tarım, ekonomi anlat desen anlatamam camiiyi anlatırım, insanlardan teşekkür de aldım, müftülükten ve yerel kurum ve kuruluşlardan dinimiz ve camimizi anlatmakta sorun yaşamıyorum. Ezanı dini, camiyi İslamı yüzde 90 anlatabiliyorum. 100 de 100 değil manevi kelimeleri anlatmak zor o konuda eksiklerimiz var. Turistler konuşurken net olarak anlaşabiliyorum. Saatlerce oturup konuşabiliyorum." ${ }^{41}$ R3'e göre, yabancı dil puanı istenilen sınavlar, cami rehberliği faaliyetinde kullanılan dil becerisini ölçmemektedir.

Görevlendirmeden kaynaklı bir diğer sorunu ise R7 şu şekilde ifade etmektedir: "Biz bu konuda mağduruz, 12-18 kilometreden gelip gidiyoruz, aylık mazot masrafım var aracımın yıpranması hariç. Bizim görevlendirmeler, işte yolluksuz, yevmiyesiz ve harç almadan diye başlar, bu büyük mağduriyettir." 42

\subsubsection{Materyal Sorunu}

Cami rehberlerinin sorunlar konusunda en çok vurguladıkları sorun alanlarından biri de materyal konusundaki sorunlardır. Bu noktada ilk dikkat çektikleri

\footnotetext{
${ }^{40}$ R2, Kişisel Görüşme, 17 Eylül 2019.

${ }^{41}$ R3, Kişisel Görüşme, 5 Eylül 2019.

${ }^{42}$ R7, Kişisel Görüşme, 18 Eylül 2019.
} 
husus yabancılara yönelik hazırlanmış, özet, detaya girmeyen, dikkat çekici yazılı materyallere olan ihtiyaçtır. Bu konuda cami rehberlerinin görüşleri şu şekildedir: "Yabancılara yönelik, hazırlanması gerek, kitaplar var ama yabancılar yönelik değil. Teferruata girmeden ana hatlarıyla anlatan kitaplara ihtiyaç var. İmam hatip okullarında okutulan kitapları çevirip onlara vermemiz uygun değildir. Müslümanlar için yazılmış bir kitabı onlara vermenin, siyer kitabını çevirip vermenin. Bakıyoruz siyer kitaplarında Hz Peygamberin savaşları anlatılıyor. Savaşları anlatan kitabı vermenin bir anlamı yok. İslam ahlakını, barıșı ele alan kitaplar gerekli. Bir Hristiyana en başta İslam adına verilmesi gereken bilgi nedir bunu düşünmemiz lazım. Savaşlardan önce peygamber efendimizin güzel huylarını, tüm huyları güzel de barıștan yana olduğu tarafları vermemiz lazım." 43

“Bakıyoruz kitaplara, Hz. Peygamber'e Hira Mağarası'nda vahiy geldi. 622'de böyle oldu. 610'da şu oldu. Bunlar zaten o dönemin tarihselliği. Ama Hz. Peygamber'in ilk neyi öğretmeye başladığılla ilgili çok fazla bir bilgi yok. Mesela, buraya bir İslam tarihi hocası geldi. "Biz yabancılarla muhatabız. İslam'ın ana mesajını ileten bir kitap var mı?" diye sordum. Bana bir kitap göndermiş. Aynı siyer ve İslam tarihi gibi bir kitap." 44

"Çok uzun metinlere ihtiyacımız yok. Yani öyle bir şeyler yazıyorlar ki buna ihtiyaç yok yani. Muhataplarımızın ilk karşılaştıklarında bıkmayacakları sıkılmayacakları bir cümle sayısına ihtiyaçları var. İki üç cümle ile bir şey anlatacaksınız çok şey yazarak anlatamazsınız adam sonuna geldiğinde başındakini unutuyorsa o iyi bir şey yapmıyorsunuz. Bolivya'ya gittiniz. Size Bolivyaca kendi dinlerini anlatıyor. Ne kadar konsantre olabilirsiniz? Bir yere kadar. Bir yer de aaah dersiniz biter. 0 yüzden materyalin içindeki mesaj kısa, öz ve dikkat çekici anlatıcıdan ziyade dikkat çekici sloganlarda olmalı. Anlatma meselesi internet çağında size düşmüyor. Altına bir sayfa yazarsınız ve ve ve diye isteyen oradan girsin, bulur. İstemeyen zaten senden orada da istemiyor, internete girmeyecek zaten. Bu konuda biraz daha detay bilgi, tabi sahadan kesinlikle destek alınmalı. Bu atölyede çalışan akademisyenlerimiz hocalarımız sahanın filtresinden geçirmeli her şeylerini. Çünkü bizim yaşadıklarımızı onların yaşama ihtimali yok. Az demiyorum yok." 45 "R2" saha tecrübesinin de materyal hazırlanması konusunda muhakkak sürece dahil edilmesi gerektiğini vurgulamaktadır.

Materyallere ilişkin öne çıkan bir diğer husus ise gelen sorulara akademik bir destekle cevaplar hazırlanması ve bunların iyi birer çeviri ile materyal haline getirilmesidir. Bu konuya dikkat çeken R2'nin görüşleri ise şu şekildedir: “Mesela bu yüz soru var ya, biz yüz soru dedik belki yüz elli belki doksan. Fark etmiyor. Bu yüz soruya bir komisyon akademik dilde cevap bulmalı. Cevapları bütün dillere yine akademik literatürde çevirmeli. Çevirilerimizin birçoğu da problemli." ${ }^{46}$

\footnotetext{
${ }^{43}$ R6, Kişisel Görüşme, 10 Eylül 2019.

${ }^{44}$ R5, Kişisel Görüşme, 3 Eylül 2019.

${ }^{45}$ R2, Kișisel Görüșme, 17 Eylül 2019.

${ }^{46}$ R2, Kişisel Görüşme, 17 Eylül 2019.
} 


\subsubsection{Turizm Rehberleri ile Yaşanan Sorunlar}

Cami rehberliği uygulamasının gündeme gelmesi ile başlayan tartışmalardan biri de turizm rehberleri ile ilgilidir. Bu konunun cami rehberlerinin çalışmalarına da yansıdığı görülmektedir. Cami rehberleri çalışmaları sırasında karşılaştıkları sorunlar arasında turizm rehberleri ile yaşadıkları sorunlara da temas etmişlerdir. Bu konuda, faaliyet alanı olarak zamanla turizm rehberi ve cami rehberliği alanının ayrıştığını ve kendi görev alanlarının oluştuğunu belirtirken, en çok vurgulanan husus ise turizm rehberlerinin hatalı veya eksik bilgiler vermesi olarak ifade edilmiştir. Bu konuda cami rehberlerinin görüşleri ise şu şekildedir:

“illk dönem bizi yanlıș anladılar, yanlış anlamaları acaba bizi camiye sokmayacaklar mı bizim yapacağımız işi mi yapıyorlar falan diye ama biz hiçbir zaman onların yolunu kesmeyi amaçlamadık çünkü ayrı şeyler onlar sadece yanlış anladılar ya da antipropagandaya kurban oldular. Onlara hep dedik ki sizin camideki danışmanınız olmayı hedefliyoruz, yani sizin dini bilgileriniz, dini bilgilerinizin sağlığı ve güncelliği konusunda bizi ve bizim ürettiğimiz kaynakları değerlendirirseniz eğer sizde kendinizi aktüel hale getirmiş olursunuz, güncellemiş̧ olursunuz. Böyle yaklaşımlarla burada konuştuktan sonra Antalya çok önemli bu cami de yıllık bir milyona yakın turist var ve benim görebildiğim rehber sayısı yaklaşık bir 300 civarı bunların birçoğu hafızamızda var arkadaş olduk yani bizi yanlış anlayanlar sonra bizimle muhabbet etmeyi istediler. Buradaki kitapçıklardan onları faydalandırdık ondan sonra camiye geldiklerinde eğer dini bir mesele varsa direk bize sorun doğru bilgiyi alın sizde rahat edersiniz kaliteniz artar muhataplarınız açısından ondan sonra pek bir problem olmadı ama her yerde olduğu gibi art niyetli, marjinal kişilerin varlı̆̆ını da inkâr etmeyiz. Bunlarla ilgili bir çalışma yapılmalı bunlar ülkenin imajına leke süren zihniyetler. Yani kendi ülkesini ve dinini, dininin aleyhinde çalışan zihniyetler. Bu anlaşılabilir bir şey değil. Bunu bir ülke kendi kendini beslemesi akıl alır bir şey değil zaten. Ona biz vatandaş olarak da görevli olarak da tepki koyuyoruz. Yani söylediğin yanlıș diyoruz. Bazı rehberleri dinliyorum kendimi tanıtmadan bilgilerini kontrol etmeye çalışıyorum. Ne yapıyor bunlar hangi dinden neden bahsediyor. ${ }^{47}$

"Bazı şeyleri yanlış söylüyorlar. Başörtüsünü sordu turist, Araplardan gelme diye anlatıyor. Ben müdahale etmek zorunda kaldım. İslam Arabistan'dan yayıldığı için öyle zannetmiş olabilir. Ama bu dinimizin gereğidir diye izah ettim. Öyle rehberler var 5 vakit namazı anlatamıyor, abdesti anlatamıyor. Bayan erkek farklı yerlerde namaz kılmasını anlatamıyor. ${ }^{48}$ Kubbede yer alan dört halifenin isimlerini Allah'ın isimleri olarak tanıtıyorlar cami hakkında bilgileri yok malesef. ${ }^{49}$

\subsection{Cami Rehberlerine En Çok Sorulan Sorular}

Cami rehberlerine en çok sorulan soruları, cami rehberliğine ilişkin sorular,

\footnotetext{
${ }^{47}$ R2, Kişisel Görüşme, 17 Eylül 2019.

${ }^{48}$ R3, Kişisel Görüşme, 5 Eylül 2019.

${ }^{49}$ R7, Kişisel Görüşme, 18 Eylül 2019.
} 
güncel politik sorular, İslam dini ile ilgili sorular şeklinde sınıflandırmak mümkündür.

\subsubsection{Cami Rehberliğine Ilișkin Sorular}

Cami rehberlerine en çok sorulan sorular arasında cami rehberliği hizmetine ilişkin sorular da yer almaktadır. Genel de hizmetin ücretsiz olup olmadığının sorulduğunu belirten cami rehberleri, zaman zaman da kendilerine yönelik soruların sorulduğunu da ifade etmişlerdir: "Ücretsiz mi diye soruyorlar. Endișeliler, onu da merak edenler var. Ücretsiz olduğunu söyleyince rahatllyorlar. Bu konuda yazı da yazacağı." 50

Cami rehberlerine yönelik sordukları soruların ise görevlinin alandaki yetkinliğini öğrenmek maksatlı olduğu görülmektedir. Bu sorulara örnek olarak R5'in açıklamaları şu şekildedir: "Eğitim profili yüksek olan ziyaretçilerimiz geldiğinde "Cami rehberliği için ne kadar zaman harcadın?" diye soruyor."51

$\mathrm{Bu}$ ifadelerden anlaşllacağı üzeri cami rehberliği hizmeti konusunda turistler bilgi sahibi değildir. Genel bir güvensizlik hali ile birlikte cami rehberi olarak karşılaştıkları kişi hakkında bilgi sahibi olmak istemektedirler.

\subsubsection{Güncel Politik Sorular}

Cami rehberlerine sorulan önemli sayıda soruyu güncel politik sorular olarak tasnif etmek mümkündür. Bu konudaki soruların çoğunlukla başta batı ülkeleri olmak üzere yurtdışındaki ülkelerdeki İslam algısı, güncel siyasi olaylar, terörizm gibi konulardan kaynaklandığı söylenebilir. Bu konuları dile getiren cami rehberlerinin ifadeleri ise şu şekildedir: "Güncel siyasi sorular sıklıkla soruluyor. Ben o insanlara "İslam, sevgiyle beslenen bir adalet dini" desem de "Sizin Müslümanlar kafa kesiyor. Nasıl oluyor bu?" diyorlar."52

"En dikkat çekici olan, günlük propagandalara çok dikkat ediyorlar. Mesela radikalizm çok sorulan bir soru. Dört kadınla evlilik, çarşaf, boşanma, herkes namaz kılmak zorunda mı, çocuklara zorla mı namaz kıldırıyorsunuz? Buna benzer niye kaç kere namaz kılıyorsunuz günde, niye kadın örtünüyor, kız çocukları özgür mü, genelde bildiklerinden dolayı değil propagandaların yansımasını görüyoruz burada. Yani Batı'ya öyle bir Müslüman, Türk imajı gidiyor bilhassa Türk değil de Müslüman imajı gidiyor o imajı burada yansıtmaya çalıșıyorlar. Günlük politikaya biraz girmek istiyorlar bizim pek girmek istemediğimiz. Ama global politika üzerine konuşmak istiyorlar, dünya işte emperyalizmin yaptıkları şunlar bunları seviyorlar. "Mesela bazı marjinal gruplar siyasetten bahsetmeyi seviyor. Şiilik, Sünnilik meselesi, Alevilik meselesi. Böyle sinir uçları konularında meraklılar. Böyle muhataplarına da böyle bir şeyler yapıyor. 0 yüzden bazıları geliyor burası Şii Camisi mi Sünni Camisi mi diyor. Bende direkt diyorum burası Müslüman

\footnotetext{
${ }^{50}$ R6, Kișisel Görüșme, 10 Eylül 2019.

${ }^{51}$ R5, Kişisel Görüşme, 3 Eylül 2019.

52 R5, Kişisel Görüşme, 3 Eylül 2019.
} 
Camisi. Hatta diyorum ki insan ibadethanesi."53

Güncel politik olarak gruplandırılan sorular incelendiğinde, turistlerin bir ön bilgi veya yargılar ile geldikleri anlașılmaktadır. Sahip oldukları yargılar üzerinden geliștirdikleri soruları ise cami rehberlerine yönelttikleri görülmektedir.

\subsection{3. İslam Dini ile İlgili Sorular}

Cami rehberlerine sorulan soruların önemli bir kısmi ise beklendiği gibi İslam dini ile ilgili sorular olduğu görülmektedir. Bu konuda cami rehberlerinin ifadeleri şu şekildedir. "Başörtüsü, abdest soranlar oluyor. Bayan erkek neden ayrı kılıyorlar. Ramazanda orucu çok soruyorlar. Anlatınca, yazın denk geldi ise ben sabahtan akşama kadar aç duramam bu çok zor. Nasıl dayanıyorsunuz diye soruyorlar." 54

"Minare sayılarını özellikle soruyorlar. Minareyi, ezanın anlamını, namaz vakitlerini, beş vakit namazı kılmakta zorlanıp zorlanmadığını soruyorlar insanların. Çalışan insanların nasıl namaz kıldığını soruyorlar. Onlar kendi ayinlerinin uzun sürdüğünden hareketle namazın da uzun olduğunu düşünüyorlar. Bir vakit namazın $10 \mathrm{dk}$ içinde kılındığını söylediğimde rahatlıyorlar." 55

"Mesela yarıyıl tatillerinde, sezon tatillerinde çocuklarıyla gelenler çocuklarına İslamı ve onun kültürünü tanıtmaya dair çaba içinde olan aileleri de görüyoruz. $\mathrm{Bu}$ okulda mukayeseli dersleri var onların. Karma dersleri Müslümanlarla Hıristiyanların beraberce yaptıkları dersler vardır. Yılda iki defa. 0 derslerde Hıristiyanlar Müslümanlığı, Müslümanlar Hıristiyanlığı öğrenir. O derslerin alt yapısı için düşünüyorlar çocukları. Çocuklar soru soruyor." 56

\section{Sonuç ve Öneriler}

Cami rehberliği hizmetini akademik çalıșmaların bir konusu haline getirme ve şu ana kadar olan sürecine ilişkin saha faaliyetinin anlaşılabilmesini amaçlayan bu çalışmada ulaşılan sonuç ve önerileri şu şekilde sıralamak mümkündür.

Cami rehberleri, cami rehberliği hizmetini, İslam kültür ve medeniyeti ve cami hakkında bilgilendirme yapmanın yanı sıra İslamofobi ile mücadele ve uluslararası alanda ülkemizin imajına katkı sağlamak olarak anlamlandırmaktadır. Cami rehberlerine sorulan sorular da bu durumu destekler niteliktedir. Soruların çoğunlukla, güncel politik ve İslam dini ile ilgili sorular olduğu tespit edilmiştir. Bu soruların arkaplanına bakıldığında İslamofobi ile ilişkili olduğu görülmektedir. Görmez'e göre İslamofobi geniş bir çerçevede ele alınan üç boyutlu bir olgudur. Bu boyutlardan birincisi, İslam dininden bağımsız olarak oluşan ve özellikle Batı ülkelerinde halk nezdinde gelişen, İslam karşısında kaygılı olma halidir. İkincisi, çoğunlukla siyasal alanda sistematik bir șekilde kendini üstün Müslümanları aşağı görme

\footnotetext{
${ }^{53}$ R2, Kişisel Görüşme, 17 Eylül 2019.

${ }^{54}$ R3, Kişisel Görüșme, 5 Eylül 2019.

${ }^{55}$ R6, Kișisel Görüșme, 10 Eylül 2019.

${ }^{56}$ R2, Kişisel Görüşme, 17 Eylül 2019.
} 
ve Müslümanları soyut, kültürel işkenceye maruz bırakma hali olarak ifade edilebilecek İslam karşıtlığıdır. Son olarak da çoğunlukla medya gücüyle, İslam korkusu olarak nitelendirilebilecek bir karşıtlık üretme çabası, İslam korkusu üretimidir. ${ }^{57}$ İslamofobinin sahaya yansıması olarak değerlendirilen söz ve eylemlere bakıldığında ise, kökenleri Batı'nın ortaçağdan beri islam algısını oluşturan ve günümüzde İslamofobinin fikri temelini oluşturan konuların özellikle İslam kılıç, şiddet dinidir, İslam şehvet ve nefse düşkünlüğü öğretiyor olarak ifade edilen kadın konusu olduğu görülmektedir. ${ }^{58}$ Şiddet dini algısının çeşitli terör örgütlerinin eylemleri üzerinden Müslümanlara ve İslam'a yöneltildiği bilinen bir gerçekliktir. İslam hakkında bilgisi medyanın sunduğu kadar olan kişilerin ise İslam şiddet ilişkisini sormaları olağan görünmektedir. Soruların yoğunlaştığı bir diğer alan da kadın konusudur. Bu konuda sıklıkla sorulan soruların, çarşaf, örtünme, çok eşle evlilik vb. olduğu anlaşılmaktadır. Bunlardan tesettür ve çarşaf konusunun oryantalist bakış açısının bir yansıması olduğu söylenebilir. Bu bakış açısına göre tesettür, kadın özgürlügünü kısıtlayan, bir baskı aracıdır. Bu baskı aracından, kadının kurtarılması da sömürgeciliğe meşruiyet zemini olarak sunulmaktadır. ${ }^{99}$ Ayrıca, Avrupa'da Müslüman kadın üzerinden İslam'ı okuma çabası sonucunda kadının şahitliği ve mirastaki payı, çok eşle evlilik, nikâhta veli şartı, kadının dayak ile cezalandırılması gibi klasik konular, bir sonraki adımda töre ve namus cinayetleri, zorla ve küçük yaşta evlilikler, kız çocuklarının okutulmaması gibi güncel meselelere kaymaktadır. Aslında bunun anlamı İslam'ın temel referanslarına ait bazı ifadelerin bağlamından koparılarak ele alındıktan sonra etnik ve kültürel kodlarla harmanlanarak sunulması, bir diğer ifadeyle, geleneğin sağlam dinî verileri gölgede bırakmasına izin verilmesidir. ${ }^{60}$ Beslenme kaynağı neresi olursa olsun, bu tarz soruların sorulması, İslamofobi'nin etki alanını göstermektedir. Bu nedenle cami rehberliğinin, İslamofobi konusunda önemli bir rol üstelendiği rahatlıkla söylenebilir. Çünkü, cami rehberlerine sorulan sorular incelendiğinde, İslamofobi ile ilişkili konu ve kavramların sorulduğu görülmektedir.

Diğer taraftan, İslamofobinin etkisinin yaygın olduğuna bir kanıt olarak 2012 yılında Allensbach Enstitüsü'nün yapmış olduğu Almanların İslam'a Karşı Yaklaşımları araştırmasının sonuçları gösterilebilir. Bu çalışmanın Frankfurter Allgemeine Zeitung'ta yayınlanan sonuçlarına göre katılımcıların \%83'ü İslam'ın kadınlara karşı ayrımcılık yaptığını düşünürken, \%77'sinin köktenci inanç ve düşüncelere bağlılık ile ilgili olduğu, \%70’lik bir kısmın ise köktenci inanç ve düşüncenin fanatizm ve radikalizmle alakalı olduğu görüşünü taşıdığı görülmüştür. Araştırma sonuçlarına göre katılımcıların \%64'ü İslam'ın şiddet ile özdeş olduğu, \%60'lık bir kesimi ise İslam'ın intikam alma ve cezalandırma ile özdeş olduğu kanaatini taşımaktadır. Katılımcıların sadece \%13’lük bir kısmı İslam’ı "komşularını

\footnotetext{
57 Mehmet Görmez, "Başyazı”, Diyanet Aylık Dergi 262 (Ekim 2012), 1.

58 Montgomery Watt, Modern Dünyada İslam Vahyi, çev. Mehmet S. Aydın (Ankara: Hülbe Yayınları, 1982), 21-22.

${ }^{59}$ Nilüfer Göle, İç içe Geçişler: İslam ve Avrupa, çev. Ali Berktay (İstanbul: Metis Yayınları, 2010, 165.

60 Huriye Martı, "İslamofobi ve Avrupa'da Müslüman Kadın İmajı", Gümüşhane Üniversitesi İlahiyat Fakültesi Dergisi 7/13 (2018), 41.
} 
sevmek" olarak görürken \%12'lik bir kısmı ise İslam'ı hayırseverlik olarak, \%7'lik bir kısmı ise şeffaf ve tolerans sahibi bir din olarak görmektedir. Bu konuda farklı araştırmaların sonuçlarının birlikte değerlendirilmesi önemlidir ancak, bu çalışma çerçevesinde katılımcıların büyük çoğunluğunun İslam'ın kadınlara yönelik ayrımcılık yaptığı ve şiddet ile özdeş bir din olduğunu düşündükleri açıktır. Bu nedenle cami rehberliğinin, İslamofobi ile mücadele konusunda önemli bir görev üstlenme potansiyelinin olduğunu söylemek yerinde olacaktır. Bu durum diğer taraftan da cami rehberliği hizmetinin önemli bir temellendirmesi olarak kabul edilebilir. ${ }^{61}$ Cami rehberliğinin, bir imaj düzeltme işlevinin olacağı da söylenebilir. Bu konuya turist rehberlerinin ülke imajına katkısının ele alındığı bir çalışmanın bulguları örnek olarak gösterilebilir. Güzel tarafından Alman turistlerin Türkiye algısına, turist rehberlerinin etkisinin araştırıldığı çalışmada, profesyonel turist rehberlerinin turistler üzerinde Türkiye'nin imajını geliştirebilecek birçok madde üzerinde olumlu yönde etki yaptığı gözlenmiștir. ${ }^{62} \mathrm{Bu}$ anlamda, cami rehberliği hizmetinin de İslamofobi ve ülke imajı noktasında katkı sağlaması muhtemeledir. Ayrıca, bu konuda turistlerin örneklem alındığı bir çalışma ile de bu etkinin olup olmadığı da araştırılabilir.

Kendine ait bir çalışma alanı edinme potansiyeli olan bu hizmeti yapacak personelde bulunması gereken yeterliklerin Başkanlığı'n personel yeterlikleri arasında yer almadığı görülmektedir. Bu nedenle ilk olarak bu hizmeti yerine getirecek personelin yeterliklerinin belirlenmesinin gerekli olduğu söylenebilir. Bu yeterliklerin neler olabileceği konusunda cami rehberlerinin en çok desteğe ihtiyaç duydukları konusundaki bulguların yol gösterici olacağı düşünülmektedir. Bu çerçevede cami rehberlerinin en çok desteğe ihtiyaçları olduğu ve bilmelerinin iyi olacağını düşündükleri hususlar ise dinler tarihi bilgisi, dil ve iletişim becerisi, rehberlik yöntemi, sanat tarihi ve mimari, yabancı dilde terminoloji bilgisi alanları olmuştur. Bu ve benzer konuların 2016 yılında yapılan çalıştayda da gündeme geldiği görülmektedir. Ancak daha sonraki yılların faaliyet raporlarında bu konulara rastlanmamıștır. Bu konular somutlaștırılacak olursa dinler tarihi ile ilgili konuda ilahiyat fakültelerinin ilgili bilim dallarından destek alınarak çalışmalar yapılabilir. Dil ve iletişim becerisi konusunda ise Furat tarafından yapılan ve ilahiyat öğrencilerinin, nitelikli din görevlisi yetiştirme açısından ilahiyat eğitimini değerlendirdikleri çalışmada, "Din görevliliğinin gerektirdiği düzeyde) iletişim bilgi ve becerisine sahip olma konusunda fakültede verilen eğitim yeterlidir" ifadesine öğrencilerin \%25,3'ü tamamen katılmıyorum, \%11'i kısmen katılmıyorum, \%18,7'si emin değilim, \%28,6 kısmen katılıyorum, \%16,5 tamamen katılıyorum şeklinde yanıt vermiştir. ${ }^{63} \mathrm{Bu}$ bulgular çerçevesinde öğrencilerin, \%36,3'ünün iletişim bilgi ve bece-

${ }^{61}$ Frankfurter Allgemeine Zeitung (Faz), "Die Furcht vor dem Morgenland im Abendland" (18 Nisan 2021).

62 F. Özlem Güzel, Türkiye İmajının Geliștirilmesinde Profesyonel Turist Rehberlerinin Rolü (Alman Turistler Üzerine Bir Araştırma) (Balıkesir: Balıkesir Üniversitesi, Sosyal Bilimler Enstitüsü, Yüksek Lisans Tezi, 2007), 147.

63 Ayșe Zişan Furat, "Nitelikli Din Görevlisi Yetiștirmede İlahiyat Fakültelerinde Sürdürülen EğitimÖğretim Faaliyetlerinin Yeterliliği: İstanbul Üniversitesi İlahiyat Fakültesi Öğrencilerinin Konu 
risi konusunda ilahiyat eğitiminin yeterli olmadığını düşündüğü söylenebilir. Buradan hareketle de ilahiyat eğitiminin ötesinde, cami rehberliği hizmetini yerine getirecek personelden bu konuda ilahiyat eğitiminin ötesinde farklı eğitimler istenmesi yerinde olacaktır. Halihazırda görev yapanlara ise üniversitelerin yabancı diller birimleri ve iletişim fakülteleri ile özellikle de kültürlerarası iletişim konusunda uzmanlardan destek sağlanabilir.

Cami rehberlerinin bu konularda kendilerini geliştirebilmeleri için hâkim oldukları yabancı dilin konuşulduğu ülkelerde görevlendirilerek dil ve kültüre yönelik kendilerini geliștirmelerine imkan tanınabilir. Sanat tarihi ve mimari alanında yine üniversitelerin ilgili bölüm ve birimlerinden destek alınması önerilebilir. Zira başta Ayasofya-i Kebîr Cami-i Şerîfi olmak üzere tarihi ve mimari açıdan öne çıkan camilerin tanıtımı noktasında bu durum daha da önemli hale gelmektedir. Yabancı dilde terminoloji konusunda ise başta Türkiye'deki ilahiyat fakülteleri ve yabancı dil bölümleri olmak üzere İslam dışı dinler konusunda uzman isimlerin de katılımıyla çalışmalar yapılarak bu konularda çözümler üretilebilir. Ayrıca, ilahiyat fakültelerinde bölümleşme çabaları arasında yer alan İngilizce İlahiyat, uluslararası ilahiyat ve dünya dinleri bölümlerinin bu hizmet alanı için kaynak program olarak konulması düşünülebilir. ${ }^{64} \mathrm{Bu}$ bölümlerin amaçları incelendiğinde cami rehberliği hizmeti ile uyumlu olduğu görülmektedir. Örneğin Ankara Üniversitesi İlahiyat Fakültesi bünyesinde bulunan Dünya Dinleri bölümünün amacının ifade edildiği sayfada “...ülkemizin çeşitli kurumlarının dünya dinleri alanında uzmanlara gereksinimlerinin olacağı düşünülmektedir. Özellikle dış ilişkilerde, ilişkide bulunulan toplumun dinsel yapısı hakkında bilgi sahibi olmak ilgili kültürü tanıma adına önemlidir." ifadeleri dikkate çekmektedir. Gerek farklı dinlere ait derinlikli bilgilerin öğrenilmesi, gerekse İngilizce olarak terminolojinin öğrenilmesi cami rehberliği hizmetinin niteliğini artıracaktır. Bu konuya ek bir öneri olarak da farklı dillerde ilahiyat bölümlerinin kurulması da bir öneri olarak getirilebilir. ${ }^{65}$

Cami rehberlerinin hizmet faaliyeti sürecinde yaşadıkları sorunların, kadro ve istihdam sorunu, materyal sorunu ve turizm rehberleri ile yaşanan sorunlar şeklinde olduğu tespit edilmiştir. Bununla birlikte 100 kişilik kadro için çıkılan ilana 23 kişinin başvuru yapmış olması her ne kadar gerekli şartları sağlayan kişi sayısının azlığına işaret etse de bir başka açıdan cami rehberliğinin yeterince anlaşılamadığı veya cazip hale getirilemediği şeklinde de yorumlanabilir. Bu noktada istihdam ve özlük haklarının iyileştirilmesi konusunda kurum içi çalışmaların yapılması ve cami rehberliğinin nitelikli kişiler için gerek çalışma şartları gerekse maddi gelir açısından arzulanır hale getirilmesi için gayret gösterilmesi yerinde olacaktır. Bu konuda Ay ${ }^{66}$ tarafından yapılan çalışmada DİB'in kendisine adil davrandığını düşünen (örgütsel adalet algısı) din görevlilerinin mesleki doyumunun

Hakkındaki Düşünceleri”, Marife Dini Araștırmalar Dergisi 12/1 (2012), 101.

${ }^{64}$ Ankara Üniversitesi İlahiyat Fakültesi (AÜİF), “Lisans Programları ve Bölümleri” (18 Nisan 2021).

${ }^{65}$ Ankara Üniversitesi İlahiyat Fakültesi (AÜİF), "Dünya Dinleri” (18 Nisan 2021).

66 Mustafa Fatih Ay, "Din Görevlilerinde Mesleki Doyum ile Örgütsel Adalet Algisı İlişkisi".

Tasavvur/Tekirdağ İlahiyat Dergisi 6/1 (Haziran 2020): 248. 
da yükseldiği tespit edilmiştir. Bu nedenle din görevlilerinin, emeğinin karşılığını gördügünü düşünmesi mesleki doyumunu dolasıyla da hizmet kalitesini olumlu yönde etkileyecektir. Cami rehberlerinin de özlük hakları ve istihdam sorunlarının çözülmesinin, hizmetin kalitesini artıracağı söylenebilir. Ayrıca yabancı dil konusunda istenilen yeterlik düzeyinin alan sınavı șeklinde düzenlenecek bir sınav ile aranması önerilebilir.

Önemli bir sorun alanı olarak görülen materyal sorunu ise cami rehberlerinin desteğe ihtiyaç duydukları konular ile eşleşmektedir. Bu konuda görüşülen cami rehberleri Başkanlığı'n yeterli sayıda materyal desteği verdiğini belirtmektedir. Ancak hitap edilen kesime uygun materyallerin uzman kişilerce hazırlanması gerektiğini belirtmektedir. Bu noktada hem akademik anlamda ilahiyat alanından başta dinler tarihi ve din eğitimi alanları olmak üzere destek alınarak hem kavramsal hem de eğitimsel olarak uzman kişilerce hazırlanması ve terminoloji konusunda da alan ve dil uzmanlarının desteğinin alınması kaçınılmaz görünmektedir. Ayrıca sunum olarak görsel ve nitelikli bir tasarım için reklam ve tasarım gibi alanların da desteğine ihtiyaç duyulacağı söylenebilir. Bu nedenle önemli bir sorun alanı olan materyal konusunda, saha tecrübesini temsilen cami rehberlerinin de katılımıyla, dinler tarihi, din eğitimi, yabancı dil uzmanları ve tasarım uzmanlarının yer aldığı bir çalışma grubu oluşturulabilir. Bir diğer sorun alanının ise turizm rehberleri ile yaşananlar olduğu görülmektedir. Bu konuda her iki rehberlik alanının sınırlarının iyi çizilmesi, uzmanlık gerektiren konuların işin uzmanına bırakılması ve işbirliği içerisinde faaliyetlerin yürütülebilmesi için ortak çalışmalar yapılabilir.

Cami rehberlerine en çok sorulan sorular arasında cami rehberliğine ilişkin soruların da olduğu tespit edilmiştir. Buradan anlaşıldığı üzere cami rehberliği konusunda turistlerin bilgi sahibi olmadığı görülmektedir. $\mathrm{Bu}$ nedenle hizmetin tanıtımı konusunda havalimanları, oteller ve turistlere yönelik hizmet alanlarında bu hizmetin tanıtımı yapılabilir. Ayrıca Kültür ve Turizm Bakanlığı tarafından hazırlanan rehber ve broşürlere cami rehberliği hizmeti de eklenebilir.

İslam dini ve güncel politik sorular konusunda da bir saha çalışması yapılarak gelen sorular belirli aralıklarla tekrarlanan süreçlerde toplanabilir. Toplanan bu sorular, oluşturulacak bir çalışma grubu tarafından değerlendirilerek, cevapları hazırlanarak cami rehberlerine bilgilendirmeler yapılabilir.

Cami rehberlerine sorulan sorular arasında bulunan güncel politik sorular ve İslam dini ile ilgili sorular bir anlamda cami rehberliği hizmetinin üzerine temellendirilmesi gereken alan olduğu görülmektedir. Bu soruları verilen hizmetin gerekliliği ve muhatabın hizmete olan ihtiyacı olarak iki boyutta ele almak mümkündür. Cami rehberlerine sorulan sorular arasında bulunan güncel politik sorular ve İslam dini ile ilgili sorular bir anlamda cami rehberliği hizmetinin üzerine temellendirilmesi gereken alan olduğu görülmektedir. Bu soruları verilen hizmetin gerekliliği ve muhatabın hizmete olan ihtiyacı olarak iki boyutta ele almak mümkündür.

Cami Rehberliği Yeterlik Çerçevesi Önerisi: Her ne kadar katılımcı sayısı veya cami rehberi sayısı az da olsa sahadan elde edilen bulgular çerçevesinde bir yeterlik çerçevesi oluşturmanın mümkün olduğu düşünülmektedir. Bir başka deyişle 
de cami rehberi olacak kişilerin alması gerekli olan eğitimler olarak nitelendirmek mümkündür. İmam-Hatip yeterliklerine ek olarak, bu hususları genel maddeler halinde şu şekilde sıralamak mümkündür.

Alan Bilgisi;

1. Başta Hristiyanlık, Yahudilik olmak üzere diğer dinlerin inanç, ibadet, mezhep, dini mekan ve sembolleri konusunda bilgi sahibi olur.

2. Ateizm, Deizm, Agnostisizm gibi akımların temel görüşleri ve dinlere yönelik eleştirileri hakkında bilgi sahibi olur.

3. Cami rehberliği yapılan yabancı dilde, bașta İslam olmak üzere Yahudilik, Hristiyanlık, diğer dinler ve Ateizm, Deizm gibi akımlara ilişkin terminolojiye hakim olur.

4. İslam sanat tarihi ve mimarisi hakkında bilgi sahibi olur.

Meslek Bilgisi;

1. Farkı din, dil ve kültürlerden kişilerle başarılı bir şekilde iletişim kurar.

2. Cami rehberliği görevini yerine getirmek için gerekli olan rehberlik becerisine sahip olur. Görev süresince ele alınan konu ve muhatabın durumunu dikkate alır.

3. Yeterli yabancı dil düzeyine sahip olur.

Ayrıntılı bir şekilde ele alınması mümkün olmakla birlikte cami rehberliği için yeterlik çerçevesinin ana hatlarının bu şekilde olabileceği söylenebilir. Bu konuda cami rehberliği için yeterlik çerçevesinin merkeze alındığı çalışmalar tasarlanarak uzman görüşleri, literatür taraması vb. çerçevesinde daha ayrıntılı sonuçlara ulaşmak mümkündür.

Sonuç olarak; cami rehberliği hizmeti uluslararası alanda İslamofobi ile mücadele, İslam dini ve ülkemizin tanıtımı gibi konularda önemli bir hizmet alanıdır. Disiplinlerarası özelliği nedeniyle kurumlar arası işbirliği ile çalışmalar yapılarak bu hizmetin kalitesinin yükseltilmesi önemlidir. Ayrıca, cami rehberlerinin daha spesifik alanlarda saha tecrübelerinin detaylı bir şekilde araştırıldığı çalışmaların yanı sıra hizmet alan turistlerin de cami rehberliği hizmetine ilişkin memnuniyet ve beklentilerinin ele alındığı çalışmalar yapılabilir.

Funding / Finansman: This research received no external funding. / Bu araştırma herhangi bir dış fon almamıştır.

Conflicts of Interest / Çıkar Çatışması: The author declare no conflict of interest. / Yazar, herhangi bir çıkar çatışması olmadığını beyan eder.

Kaynakça

AÜİF, Ankara Üniversitesi İlahiyat Fakültesi. "Dünya Dinleri”. 18 Nisan 2021. http://www.divinity.ankara.edu.tr/?page_id=294

AÜİF, Ankara Üniversitesi İlahiyat Fakültesi. "Lisans Programları ve Bölümleri". 18 Nisan 2021. http://www.divinity.ankara.edu.tr/?page_id=955

Ay, Mustafa Fatih. "Din Görevlilerinde Mesleki Doyum ile Örgütsel Adalet Algısı İlişkisi". Tasavvur/Tekirdağ İlahiyat Dergisi 6/1 (Haziran 2020), 231-254. 
Creswell, John. W. Nitel Araștırma Yöntemleri: Beș Yaklaşıma Göre Nitel Araștırma ve Araştırma Deseni. ed. Mesut Bütün - Selçuk Beşir Demir. Ankara: Siyasal Kitabevi, 2015.

DİB, Diyanet İșleri Başkanlığı. "Diyanet İșleri Başkanlığı Personel Yeterlikleri". (Erişim 19 Ocak

https://hukukmusavirligi.diyanet.gov.tr/Documents/Diyanet $\% 20 \%$ C4\%B0\%C5\%9 Fleri\%20Ba\%C5\%9Fkanl\%C4\%B1\%C4\%9F\%C4\%B1\%20Personel\%20Yeterlikleri. pdf

DİB, Diyanet İșleri Başkanlığı. "Cami Rehberliği Hizmetleri”. Erișim 19 Ocak 2020. https://dinhizmetleri.diyanet.gov.tr/detay/97/cami-rehberli\%C4\%9Fi-hizmetleri

DİB, Diyanet İşleri Başkanlığı. "Diyanet İşleri Başkanlığı, Diyanet İşleri Başkanlığı Görev ve Çalıșma $\quad$ Yönergesi”. $\quad$ Erișim $19 \quad$ Ocak 2020. https://hukukmusavirligi.diyanet.gov.tr/Documents/Diyanet $\% 20 \%$ C4\%B0\%C5\%9 Fleri\%20Ba\%C5\%9Fkanl\%C4\%B1\%C4\%9F\%C4\%B1\%20G\%C3\%B6rev\%20ve\%20 \%C3\%87al\%C4\%B1\%C5\%9Fma\%20Y\%C3\%B6nergesi.pdf

DİBDHGM, Diyanet İșler Bașkanlığı Din Hizmetleri Genel Müdürlüğü. Faaliyet Raporu 2016. Ankara: Diyanet İșleri yayınları, 2017.

DİBKGHK, Diyanet İşleri Bașkanlığı Kuruluş ve Görevleri Hakkında Kanun (Kanun No. 633, md. 1.). Resmî Gazete 12038 (2 Temmuz 1965). 19 Ocak 2020. https://hukukmusavirligi.diyanet.gov.tr/Documents/GÖREV VE ÇALIȘMA YÖNERGESI 4.12.2019.pdf

DİBSGB, Diyanet İşler Başkanlığı Strateji Geliștirme Başkanlığı. 2013 Yılı Faaliyet Raporu. Ankara: Diyanet İşleri Yayınları, 2014.

DİBSGB, Diyanet İşler Başkanlığı Strateji Geliștirme Başkanlığı. 2014 Yılı Faaliyet Raporu. Ankara: Diyanet İşleri Yayınları, 2015.

DİBSGB, Diyanet İşler Başkanlığı Strateji Geliştirme Başkanlığı. 2015 Yılı Faaliyet Raporu. Ankara: Diyanet İşleri Yayınları, 2016.

DİBSGB, Diyanet İşler Başkanlığı Strateji Geliştirme Başkanlığı. 2016 Yılı Faaliyet Raporu. Ankara: Diyanet İşleri Yayınları, 2017.

DİBSGB, Diyanet İşler Başkanlığı Strateji Geliștirme Başkanlığı. 2017 Yılı Faaliyet Raporu. Ankara: Diyanet İşleri Yayınları, Tarihsiz.

DİBSGB, Diyanet İşler Başkanlığı Strateji Geliștirme Başkanlığı. 2018 Yılı Faaliyet Raporu. Ankara: Diyanet İşleri Yayınları, Tarihsiz.

DİBSGB, Diyanet İşler Başkanlığı Strateji Geliștirme Başkanlığı. 2019 Yılı Faaliyet Raporu. Ankara: Diyanet İşleri Yayınları, Tarihsiz.

FAZ, Frankfurter Allgemeine Zeitung. "Die Furcht vor dem Morgenland im Abendland". 18 Nisan 2021. https://www.faz.net/aktuell/politik/inland/allensbach-studie-diefurcht-vor-dem-morgenland-im-abendland-11966471.html

Furat, Ayșe Zișan. "Nitelikli Din Görevlisi Yetiștirmede İlahiyat Fakültelerinde Sürdürülen Eğitim-Öğretim Faaliyetlerinin Yeterliliği: İstanbul Üniversitesi İlahiyat Fakültesi Öğrencilerinin Konu Hakkındaki Düşünceleri”. Marife Dini Araştırmalar Dergisi 12/1 (2012), 83-110.

Göle, Nilüfer. İç içe Geçişler: İslam ve Avrupa. çev. Ali Berktay. İstanbul: Metis Yayınları, 2010. Görmez, Mehmet. "Başyazı". Diyanet Aylık Dergi 262 (Ekim 2012), 1.

Güzel, F. Özlem. Türkiye İmajının Geliștirilmesinde Profesyonel Turist Rehberlerinin Rolü (Alman Turistler Üzerine Bir Araştırma). Balıkesir: Balıkesir Üniversitesi, Sosyal Bilimler Enstitüsü, Yüksek Lisans Tezi, 2007.

İM, İstanbul Müftülüğü. "Diyanet İşleri Başkanlığı Cami Rehberi Alım İlanı”. Erişim 19 Ocak 2020.

https://istanbul.diyanet.gov.tr/Sayfalar/ContentDetail.aspx?MenuCategory=Kurums al2\&ContentCategory=personelimiz

M, Memurlar. "Camileri Özel Rehber Tanıtacak, Bu Amaçla 250 Kişi Alınacak". Erişim 19 Ocak 2020. https://www.memurlar.net/haber/214201/camileri-ozel-rehber- 
tanitacak-bu-amacla-250-kisi-alinacak.html

M, Memurlar. "Diyanet İșleri Başkanlığı Cami Rehberi Alım İlanı”. Erişim 19 Ocak 2020. https://ilan.memurlar.net/ilan/23864/diyanet-isleri-baskanligi-cami-rehberi-alimilani.html

Martı, Huriye. "İslamofobi ve Avrupa'da Müslüman Kadın İmajı”. Gümüşhane Üniversitesi Illahiyat Fakültesi Dergisi 7/13 (2018), 36-46.

Watt, Montgomery. Modern Dünyada İslam Vahyi. çev. Mehmet S. Aydın. Ankara: Hülbe Yayınları, 1982.

Yıldırım, Ali - Șimșek, Hasan. Sosyal Bilimlerde Nitel Araștırma Yöntemleri. Ankara: Seçkin Yayıncllık, 2006. 